\title{
Investigation of Salmonella Spp Presence in the Lettuce Production Destined for School Meal in Farms of Family Farming in Southern Brazil
}

\author{
Elis Regina Gomes Alfama (I), Susana Elias (I), Mariângela \\ Santiago Terra (I), Ana Beatriz Almeida de Oliveira (II), Eduardo \\ Tondo (I) \\ (I) UFRGS - Universidade Federal de Rio Grande do Sul (Avenida Bento Gonçalves, 9500 \\ Prédio 43212 Laboratório 205 Porto Alegre/RS), (II) UFRGS - Universidade Federal de Rio \\ Grande do Sul (Rua Ramiro Barcelos, 2400/4 andar Porto Alegre/RS CEP 90035-003)
}

\section{Resumo}

Lettuce (Lactuca sativa) is one of the most commonly consumed leafy vegetables worldwide. In Brazil, the green-leaf lettuce is the most planted and consumed. It is widely used in the public schools menus of many cities in Rio Grande do Sul. However, the sanitary conditions of Brazilian rural properties are largely unknown and may not be ideal, because many food outbreaks have been reported involving fruits and vegetables consumption. Moreover, this vegetable is offered for 159 public schools located in the cities of São Leopoldo, Itati, Terra de Areia, Três Forquilhas and Porto Alegre, totaling 86,142 students monthly. Therefore, this study aimed to evaluate the primary production chain of lettuce from conventional (not organic) farms, investigating the presence of Salmonella spp. Four farms located on the northern coast of southern Brazil were investigated in the period July/2013 until May/2014. A total of 198 samples were collected, including lettuce, soil, manure, irrigation water and washing water. They were analyzed for Salmonella spp. according to ISO 6579:2007, using as positive control the strain S. Enteritidis SE86. Six samples were contaminated by Salmonella spp. (lettuce, soil and manure, two isolates of each). These isolates were sent to Oswaldo Cruz Institute for a conclusive antigen diagnostic. The likely contamination may have occurred due to

\footnotetext{
Referência:

Elis Regina Gomes Alfama, Susana Elias, Mariângela Santiago Terra, Ana Beatriz Almeida de Oliveira (II), Eduardo Tondo. Investigation of Salmonella Spp Presence in the Lettuce Production Destined for School Meal in Farms of Family Farming in Southern Brazil. In: Anais do 12 Congresso Latinoamericano de Microbiologia e Higiene de Alimentos - MICROAL 2014 [= Blucher Food Science Proceedings, num.1, vol.1]. São Paulo: Editora Blucher, 2014.

DOI 10.5151/foodsci-microal-148
} 
composting time of organic fertilizer (poultry and swine feces) used in planting, because it was not controlled. Another relevant factor is that the water used to the planting irrigation is also used for livestock drinking; this fact may allow the water contamination by feces of animals, because floods could lead this contamination to within these water reservoirs. The results suggest the need of the Good Agricultural Practices implementation in these farms, in order to prevent further outbreaks involving this kind of food, as well as the cleaning of these vegetables with chlorinated water before consumption, as specified by the State Ordinance of the Rio Grande de Sul Number 78 of 2009.

Palavras-Chave: Conventional lettuce, Salmonella, family farming, production chain, microbiological analysis

Agência de Fomento: CAPES 